\title{
A Study on the Legal Mechanisms of Jointly Building the 21st-Century Maritime Silk Road Between China and ASEAN
}

\author{
Li Renda ${ }^{1}$, Zou Ligang ${ }^{2}$ \\ ${ }^{1}$ Department of Law, Hainan Academy of Governance, Haikou, China \\ ${ }^{2}$ Law School, Hainan University, Haikou, China
}

Email address:

lirenda@126.com (Li Renda), zouligang999@163.com (Zou Ligang)

To cite this article:

Li Renda, Zou Ligang. A Study on the Legal Mechanisms of Jointly Building the 21st-Century Maritime Silk Road Between China and ASEAN. Humanities and Social Sciences. Vol. 6, No. 4, 2018, pp. 109-113. doi: 10.11648/j.hss.20180604.12

Received: June 18, 2018; Accepted: July 2, 2018; Published: August 2, 2018

\begin{abstract}
China advocates the spirit of the 21st-Century Maritime Silk Road (21CMSR) -"peace and cooperation, openness and inclusiveness, mutual learning and mutual benefit". The routes of the 21CMSR need to certainly passage the South China Sea (SCS) which is surrounded by China and ASEAN countries, therefore, the jointly building the 21CMSR between China and ASEAN is a geographically natural mission. The process of jointly building shall depend on a wide range of cooperations and exchanges, which is explicitly stipulated by UN Charter, the UNCLOS, the DOC as well as many other regional agreements and documents. To construct the legal mechanisms is a significant guarantee for clarifying each party's rights and obligations and promoting their cooperations and exchanges. As a consequence, China and ASEAN should jointly build some particularly crucial legal mechanisms including a code of conduct in the SCS which should be endowed the binding force, a mechanism of the regional economic and trading cooperation, a mechanism of the regional connectivity and a mechanism of the environmental protection.
\end{abstract}

Keywords: China, ASEAN, 21CMSR, Legal Mechanisms

\section{Introduction}

The Silk Road Economic Belt and the 21st-Century Maritime Silk Road, also known as One Belt One Road, is a long-term development initiative proposed by China's President $\mathrm{Xi}$ Jinping when he visited Central Asia and Southeast Asia respectively in 2013. As a specifically practical reflection of China's neighborhood diplomacy of amity, sincerity, mutual benefit and inclusiveness, the spirit of 21CMSR is advocated by China as-"peace and cooperation, openness and inclusiveness, mutual learning and mutual benefit". [1] In such a spiritual guidance, the 21CMSR will be an unblocked bridge between China and the nations along with it. So far, over 100 countries and international organizations have responded positively to the initiative and pledged their support. More than 80 countries and international organizations have signed cooperation agreements with China. [2].

According to Vision and Actions on Jointly Building the
Silk Road Economic Belt and 21st-Century Maritime Silk Road which issued by the National Development and Reform Commission (NDRC) and several other ministries of China in March 2015, the 21CMSR is designed to go from China's coast to Europe through the SCS and the Indian Ocean in one route, and from China's coast through the SCS to the South Pacific in the other. Both of the routes needs to passage the SCS which is surrounded by China and ASEAN countries. Therefore, the jointly building the 21CMSR between China and ASEAN is a geographically natural mission.

\section{The Basis of International Law of Co-constructing the 21CMSR}

For the common interests of peace and development, jointly building the 21CMSR shall depend on a wide range of 
cooperations and exchanges for the relevant countries, which is explicitly stipulated by the UN Charter, UNCLOS, Declaration on the Conduct of Parties in the South China Sea (DOC) and many other agreements and documents reached by China and ASEAN.

\subsection{The Basic Principles of the UN Charter}

The "international co-operation in solving international problems" which stipulated in the Article 1 of the UN Charter is one of the three purposes of the UN, one of the features of China's foreign policy principles which can be defined as the mutually beneficial cooperation and the common development, and one of the spirits of the Article 1 of the ASEAN Charter. Within such a framework, China and ASEAN have a common vision of strengthening cooperations and exchanges in economic, social, cultural, political and many other fields.

\subsection{The Cooperative Mechanisms Under the UNCLOS}

It is defined that the states concerned in a spirit of understanding and cooperation, shall make every effort to enter into provisional arrangements of a practical nature in the delimitation both of the exclusive economic zone (EEZ) and the continental shelf (CS) under Articles 74 and 83 of the UNCLOS. The provisional arrangement is not a situation of zero-sum game, but a process for a win-win cooperation. It not only guarantees their own interests, but also does not harm the interests of other countries. [3].

It also provides that states bordering an enclosed or semi-enclosed sea should cooperate with each other in the exercise of their rights and in the performance of their duties under Article 123 of the UNCLOS. The bordering states of the SCS should apply this provision in managing this semi-enclosed sea. [4] Due to the different meanings of the legal words"shall" and "should", the legal nature of the duty to cooperate under the Article 123 is not without controversies. [5] However, although there is an ambiguous comprehension that whether there exists the mandatory duties of cooperations for the SCS countries, a hortatory obligation is at least existed through a generally unbaised explanation.

\subsection{The Cooperative Requirements of the DOC}

The Article 6 of the DOC specifically stipulates that the member states of ASEAN and China may explore or undertake cooperative activities in ranges of marine environmental protection, marine scientific research, safety of navigation and communication at sea, search and rescue operation and combating transnational crime before the disputes earn a comprehensive and durable settlement. China hopes to involve with other relevant countries to co-construct the mechanisms of guarantee of the implementing of the DOC and to safeguard the peace, development and stability of the SCS.

\subsection{The Relevant Agreements and Documents between China and ASEAN}

In November 2002, China and ASEAN signed the Framework Agreement on Comprehensive Economic Cooperation which stipulated a prospective of creating an ASEAN-China Free Trade Area (ACFTA) within 10 years. As the largest free trade area in the world in terms of population and third largest in terms of nominal GDP, ACFTA came into effect on January 1, 2010. In November 2004, China and ASEAN signed the Agreement on Trade in Goods of the Framework Agreement on Comprehensive Economic Co-operation. Besides, there are many other agreements or documents between China and ASEAN countries like the 2006 Agreement on Trade in Services of the Framework Agreement on Comprehensive Economic Cooperation, 2010 ASEAN-China Leaders Joint Statement on Sustainable Development, etc.

All of these agreements and documents obviously promote the China-ASEAN cooperations which should be seen as common interests to all SCS countries. It can be affirmed that with the concerned efforts by multiple sides, the legal mechanisms should be enabled to accomplish.

\section{The Recommendations on the Legal Mechanisms of Jointly Building the 21CMSR}

Finally and most basically, the good order at sea means that nations are able to pursue their legitimate maritime interests in accordance with agreed principles of international law. [6] The promotion of regional cooperations lies on the institutionalization of regional behaviors. Currently the developmental situations of the 21CMSR are still in the prototype stage, which needs to further improve the establishments of specialized mechanisms. The purpose incorporating governmental actions into the legal tracks is an important measure to guarantee the initialtive of the 21CMSR to grasp the due effectiveness.

\subsection{A Code of Conduct Which Should Be Endowed the Binding Force}

The political tension may exert an adverse effect on the development of cooperation. Therefore, for regulating relevant parties'behaviours, it is an institutional assurance in the process of co-constructing the 21CMSR that makes a code of conduct in SCS (COC) with the binding force because the enforcementlacking DOC did not make the contracting parties realize a solution for most of the disputes since the signition of it in 2002, though the preamble of the DOC promised to"enhance favourable conditions for a peaceful and durable solution of differences and disputes among countries concerned." The time was right for establishing a COC for activities in the SCS since 1990s. [7] But the process of negotiating a COC has been hard and struggling. The Article 10 of the 2002 DOC had called on the parties to adopt a COC. [8]. 
Nowadays, the complex relationship between China and ASEAN combines aspects of cooperation and tension. Actually, the current territorial and maritime jurisdiction disputes in the SCS are the major irritant in relations between China and the claimant states of Southeast Asia- Brunei, Malaysia, the Philippines, and Vietnam. [9] It is said that a stable maritime environment is essential to realize our collective regional aspirations. [10] What is needed now is that a COC to overcome the DOC's enforcement-lacking weaknesses as well as to face and resolve the new challenges that have arisen since 2002.

In september 2013, China and ASEAN agreed to follow the "step by step and to reach consensus through consultation" approach to the process of the COC during the 6th Senior Officials Meeting on the Implementation of the DOC held in Suzhou China. The goal of COC will aim to construct an increasingly mutual and stepped-up cooperation although the COC process will be significantly delayed or laborious, contrary to the expectations of many regional states and external powers. In order to remove disturbances and properly handle the SCS issue, the COC should not only mean the handling of bilateral disputes by the countries directly concerned through negotiations, but also indicate the maintenance of peace and stability in the SCS through joint efforts of China and the every member of ASEAN, which is named the Dual Track.

\subsection{A Mechanism of the Regional Economic and Trading Cooperation}

At the economic level, it is believed that through economic interdependency the potential for conflict among states can be reduced. [11] China and ASEAN trade started from a very low level. However, it has been increased quickly and now they have become very important trade partners. In the mid1980s, Deng Xiaoping proposed an economic approach to the SCS by "shelving disputes and seeking joint development" which reflects a positive attitude for the regional cooperation. At the height of the 1997-1998 Asian financial crisis, China and ASEAN forged a closer relationship. [12] Subsequently, both of China and ASEAN decided to establish a good neighborly partnership of mutual trust that is oriented toward the 21 st century in 1990s. After approximately three decades, as a consequence, the cooperations reached a new hights. Currently, China has been Asean's largest trading partner for the past eight years and Asean has been China's third-largest trading partner for six years. [13] China and ASEAN countries need to further strengthen economic and trading cooperations in the process of co-constructing the 21CMSR for sharing the benefit of development.

The ASEAN countries may be seen as a diverse region with great differences in economic developments, political systems, economic and trade systems, religious beliefs and foreign policies, subsequently, the economic and trading ties between China and ASEAN countries sometimes are hampered by some relevant reasons like the differences in law, the gaps in science and technology, etc.

In order to promote the cooperations in various fields like trading, investment, finance and service, the government of the member states of ASEAN and China should encourage to facilitate processes of economic and trading cooperations, which means that the customs procedures should be simplified, the tariffs should be reduced, the settlements of currencies shoud be more free, the standards of the inspection and quarantine should be regulated and evenentually, the trade barriers should be eliminated to the lowest level.

\subsection{A Mechanism of the Regional Connectivity}

Adopted on October 28, 2010 through the Hanoi Declaration on the Adoption of the Master Plan on ASEAN Connectivity (MPAC), MPAC is mainly a cooperative plan that aims to enhance the region's physical infrastructure, institutions and people-to-people relations. However, China's 21CMSR initiative could not be seen as a challenge to MPAC but a complement. According to most Chinese scholars including the author, it will deepen China-ASEAN economic relations as it promotes "common development and prosperity" between China and ASEAN. [14].

The 21CMSR will in fact complement ASEAN connectivity. There were a range of sincere actions made by China, incuding in 2009, China established the ChinaASEAN Investment Cooperation Fund and provided credit lines of 15 billion to mainly support ASEAN countries' infrastructures; in 2011, China declared to provide another 10 billions of loans to ASEAN; in 2015, China pledged infrastructure loans totaling 10 billion dollars to ASEAN countries and proposed railway and production capacity cooperation amid closer partnership with the economically converging region, etc. All these measures have exerted a significant role in establishing the connectivity between those countries.

ASEAN political leaders are enthusiastic for connecting in some fields across ASEAN as well as China and other countries. [15] Currently both sides have made some progress in China-ASEAN connectivity, covering projects like the Kunming-Bangkok Highway, the Trans-Asian Railway, and more flight linkages. Thay have also began to carry out maritime connectivity cooperation. [16] Particularly, in April 13, 2018, China planned to build Hainan -the southernmost part of China and the nearest province of China to the ASEAN- into a pilot free trade zone and a free trade port, which needs honestly to enhance the maritime connectivity between Hainan and the SCS countries and regions. For the purpose of establishing a sound mechanism of regional connectivity, the core tasks of the connectivity between China and ASEAN should be to reduce the bureaucratic procedures for handling cross-border trade, to improve the capabilities of standardization management, to coordinate and eliminate a variaty of obstacles and to standardize the rights and obligations of all parties.

\subsection{A Mechanism of the Environmental Protection}

As one of the most busy channels and one of the most rich regions with oil and gas resources worldwide, the SCS is under the threats of the pollution from vessels and 
installations and devices used in exploration or exploitation of the natural resources of the seabed and subsoil. The environmental problem in particular oil pollution usually causes enormous economic losses and great damage to the environment. If the occurring of environmental problem in particular the oil pollution will be confronted by the SCS countries, like the oil spill in the Gulf of Mexico in 2010 and the ConocoPhillips oil leak in Bohai Bay in 2011, the ecosystem will be severely damaged and will be difficult to restore for a long time. Therefore, building a low sensitive cooperation mechanism in particular the environmental protection in SCS will be not only an effective way to control pollution, but also an important carrier for co-construting the 21CMSR. Actually, though China is not a member of ASEAN, it maintains close cooperation in particular in the area of environmental cooperation. [17].

There are many international treaties for preventing and controlling the marine pollution, like 1969 Intemational Convention Relating to Intervention on the High Seas in Cases of Oil Pollution Casualties, 1972 Convention on the Prevention of Marine Pollution by DumPing of Wastes and Other Matter, 1973 Intemational Convention for the Prevention of Pollution from Ships, 1982 UNCLOS (in particular the Part 12), 1992 Intemational Convention on Civil Liability for Oil Pollution Damage, 2001 Intemational Convention on the Control of Harmful Anti-fouling Systems on Ships, 2009 Intemational Convention for the Safe and Environmentally Soung Recycling of Ships, etc.

A wide variety of regional mechanisms have been constructed all over the world as well, such as the Northeast Atlantic Environment Strategy, the Environmental Cooperation in the Baltic Sea Region, the Arctic Environmental Protection Strategy as well as the Regional Cooperation in the Mediterranean. These treaties and mechanisms, both international and regional, all should be referenced effectively by the SCS states for the purpose of a better marine protection. Currently, one of the available recommendations is developing a comprehensive environment monitoring system for the SCS. [18].

\section{Conclusion and Prospective}

As the antagonisms remain occasionally in the SCS, the overall purpose of China's initiative of 21CMSR is just to avoid conlict of the region and promote the cooperation. As we look to the future, these legal mechanisms - the COC, the Regional Economic and Trading Cooperation, the Regional Connectivity and the Environmental Protection - will not only give a strong boost to the economic development between China and ASEAN, but also make a more important contribution to the social progress, the cultural communication as well as the mutual trust of politics, which will establish a more stable foundation for the 21CMSR.

\section{Acknowledgements}

This research is supported by the Major Program of the
National Planning Office of Philosophy and Social Science of China (No. 16ZDA073), and by the Project of the Philosophy and Social Science of Hainan Province (No. HNSK (QN) 18-80).

\section{References}

[1] NDRC and SOA, Vision for Maritime Cooperation under the Belt and Road Initiative, June 20, 2017.

[2] Liangyu, China, Britain Expect More Results from Belt and Road Initiative Cooperation: Expert, http://www.xinhuanet.com/english/201801/29/c_136932992.htm. XinHuaNet, Jaunary 29, 2018.

[3] CAO Wei, Place on the Shelf for the Time Being DiplomacyA New Exploration into the Diplomacy Idea in Dealing with Territorial Disputes, Pacific Journal, 2011(1), pp. 67-68.

[4] Nien-Tsu Alfred Hu and Ted L. McDorman, Maritime Issues in the South China Sea: Troubled Waters os A Sea of Opportunity, Routledge Publishers, 2013, p. 144.

[5] Zhang Hua, On the Legal Obligation and Prospect of Cooperation between Parties Involved in the Disputes on South China Sea, Pacific Journal, 2016(1), p. 10.

[6] Sam Bateman and Ralf Emmers, Security and International Politics in the South China Sea, Taylor \& Francis Group, 2009, p. 238.

[7] Mark J. Valencia, Jon M. Van Dyke and Noel A. Ludwig, Sharing the Resources of the South China Sea, University of Hawaii Press, 1999, p. 120.

[8] Song Yann-huei and Zou Ke-yuan, Major Law and Policy Issues in the South China Sea:European and American Perspectives, Dorset Press, pp. 207-208.

[9] Carlyle A. Thayer, ASEAN, China and the Code of Conduct in the South China Sea, SAIS Reviews of International Affairs, 2013(33), p. 75.

[10] C. J. Jenner and Tran Truong Thuy, the South China Sea: A Crucible of Regional Cooperation or Conflict Making Soverignty Claims? Cambridge University Press, 2016, p. 119.

[11] Wu Shicun and Nong Hong, Recent Devolpments in the South China Sea Dispute: The Prospect of a Joint Devolpment Regime, Taylor \& Francis Group, 2014, p. 175.

[12] Nargiza Salidjanova and Iacob Koch-Weser, China's Economic Ties with ASEAN: A Country-by-Country Analysis, U. S.-China Economic and Security Review Commission Staff Research Report, March 17, 2015, p. 3.

[13] Dandan Wan. China and Japan rivalry in ASEAN, http://www.eu-asiacentre.eu/pub_details.php?pub_id=233. EU-ASIA centre, February 23, 2018.

[14] Joycee A. Teodoro. ASEAN's Connectivity Challenge. https://thediplomat.com/2015/06/aseans-connectivitychallenge/. The Diplomat, June 27, 2015.

[15] Sanchita Basu Das, Enhancing ASEAN's Connectivity, Institute of Southeast Asian Studies Publishing, 2013, p. 48.

[16] David B. H. Denoon, China, the United States, and the Future of South China Sea, New York University Press, 2017, p. 315. 
[17] Vu Hai Dang, Marine Protected Areas Network in the South China Sea: Charting a Course for Future Cooperation, Martinus Nijhoff Publishers, 2014, pp. 129-130.
[18] Wu Shicun, Solving Disputes for Regional Cooperation and Development in the South China Sea: A Chinese Perspective, Chandos Publishing, 2013, p. 166. 